\title{
Analisa Penjatuhan Sanksi Administrasi Dan Sanksi Pidana Dalam Penanganan Tindak Pidana Perbankan Ditinjau Dari Undang-Undang Nomor 21 Tahun 2011 Tentang Otoritas Jasa Keuangan Dan Undang-Undang Nomor 7 Tahun 1992 Tentang Perbankan Beserta Perubahannya
}

\author{
Satria Anggara Pinandita \\ Mahasiswa Pascasarjana Fakultas Hukum Universitas Indonesia \\ Korespondensi: satriaanggarap@gmail.com
}

\begin{abstract}
Criminal acts, crimes, and law violations continue to evolving along with the development of technology and economic growth. Which also results in the arising of crime in the banking sector. In the prevailing laws and regulations, Crime in the Banking Sector may be subject to criminal and administrative sanctioning. Criminal sanctions and administrative sanctions against Crimes in Banking are regulated in Law Number 21 of 2011 concerning the Financial Services Authority and Law Number 7 of 1992 concerning Banking. In the imposition of criminal sanctions and administrative sanctions, individuals and Financial Services Institutions in the Banking Sector can be imposed.
\end{abstract}

Keywords: Banking Crime, Banking, Criminal Sanctions, Administrative Sanctions

\begin{abstract}
Abstrak
Tindak pidana, kejahatan, dan pelanggaran hukum terus berkembang seiring dengan berkembangnya teknologi dan pertumbuhan ekonomi. Salah satunya lahirnya Kejahatan di Bidang Perbankan. Dalam peraturan perundang-undangan yang berlaku, Kejahatan di Bidang Perbankan dapat dijatuhi sanksi pidana dan sanksi administratif. Sanksi Pidana dan sanksi administratif terhadap Kejahatan di Bidang Perbankan sendiri diatur di dalam Undang-Undang Nomor 21 Tahun 2011 tentang Otoritas Jasa Keuangan dan Undang-Undang Nomor 7 Tahun 1992 tentang Perbankan. Dalam penjatuhan sanksi pidana maupun sanksi administratif tersebut dapat dijatuhi kepada individu maupun kepada Lembaga Jasa Keuangan di Sektor Perbankan itu sendiri.
\end{abstract}

Kata Kunci: Kejahatan Perbankan, Perbankan, Sanksi Pidana, Sanksi Administratif

\section{PENDAHULUAN}

\section{Latar Belakang}

Besarnya dampak yang ditimbulkan akibat pengelolaan bank yang tidak profesional, telah mendorong pemerintah melakukan tindakan preventif maupun represif melalui pengaturan bisnis perbankan. Secara normatif, pengaturan aktivitas perbankan tertuang dalam Undang-Undang Nomor 7 Tahun 1992 Tentang Perbankan beserta peraturan dan Putusan Mahkamah Konstitusi yang merubah norma-norma tertentu di dalamnya ("Undang-Undang Perbankan"), dan peraturan perundang-undangan lainnya. Berdasarkan pengaturan tersebut, bank wajib melaksanakan kepatuhan terhadap pelbagai peraturan perundang-undangan dan menerapkan prinsip kehati-hatian (prudential banking regulation).

Undang-Undang Perbankan dan Undang-Undang Nomor 21 tahun 2011 tentang Otoritas Jasa Keuangan ("UndangUndang OJK") telah mengatur perbuatanperbuatan yang dilarang untuk dilakukan oleh baik oleh bank sebagai badan hukum maupun individu yang menjadi bagian dalam kegiatan operasional pengelolaan bank, sehingga apabila perbuatan tersebut tetap dilakukan akan berdampak pada pengenaan sanksi administratif maupun sanksi pidana bagi si pelaku. Adapun perbuatan yang dilarang dan merupakan pelanggaran hukum di bidang perbankan tersebut dikenal juga sebagai Kejahatan di Bidang Perbankan. 
Jenis-jenis Kejahatan di Bidang perbankan adalah kegiatan yang bertentangan dengan hukum yang berkaitan dengan Perizinan, Rahasia Bank, Usaha Bank, dan Pengawasan dan Pembinaan Bank. Adapun perlu dicatat bahwa Kejahatan di Bidang Perbankan yang dapat secara tegas dapat dikenakan sanksi administratif ataupun sanksi pidana hanyalah perbuatan-perbuatan yang disebut tegas oleh peraturan perundangundangan.

Bahwa istilah Kejahatan di Bidang Perbankan merupakan perbuatan yang merupakan perbuatan melanggar hukum dalam pelaksanaan kegiatan di bidang jasa usaha perbankan. Adapun dalam kejahatan di bidang perbankan diidentifikasi sebagai kejahatan atau pelanggaran di bidang perbankan dimana kejahatan atau pelanggaran tersebut dilakukan dalam rangka melaksanakan kegiatan usaha di bidang jasa perbankan. Selain itu kejahatan dan pelanggaran di bidang perbankan juga mencakup pula segala jenis perbuatan yang bertentangan dengan hukum yang berhubungan dengan kegiatan-kegiatan dalam usaha menjalankan kegiatan perbankan itu sendiri.

Secara terminologi, istilah tindak pidana perbankan berbeda dengan tindak pidana di bidang perbankan. Tindak pidana di bidang perbankan menyangkut perbuatan yang berkaitan dengan perbankan dan diancam dengan pidana, meskipun diatur dalam peraturan lain. Di samping merupakan perbuatan yang melanggar ketentuan dalam Undang-Undang Perbankan, perbuatan tersebut juga merupakan melanggar ketentuan di luar Undang-Undang Perbankan yang dikenakan sanksi berdasarkan, antara lain, Kitab Undang-Undang Hukum Pidana (KUHP), Undang-Undang Tindak Pidana Korupsi, Undang-Undang Tindak Pidana Pencucian Uang, di mana perbuatan dimaksud berhubungan dengan kegiatan menjalankan usaha bank seperti pencucian uang (money laundering) dan korupsi yang melibatkan bank. Sementara itu, tindak pidana perbankan lebih tertuju kepada perbuatan yang dilarang dan diancam pidana yang termuat khusus hanya dalam Undang-Undang Perbankan. Pengertian tindak pidana perbankan adalah tindak pidana yang memenuhi unsur-unsur sebagaimana dimaksud dalam Pasal 46 sampai dengan Pasal 50A Undang-Undang Perbankan.

Apabila mengkaji subjek hukum dalam rumusan Pasal 48 ayat (2) Undang-Undang Perbankan, maka subjek hukum dalam pasal sebagaimana dimaksud terdiri atas anggota dewan komisaris, direksi, atau pegawai bank, sehingga apabila salah satu dari subjek hukum tersebut melakukan tindak pidana (pelanggaran), maka pembebanan pidana secara langsung ada pada subjek hukum dimaksud. Namun demikian, meskipun pembebanan pidana langsung dikenakan kepada subjek hukum yang melakukan tindak pidana, bukan berarti bank tidak dapat bertanggungjawab secara administratif maupun perdata, apabila tindak pidana yang dilakukan subjek hukum tersebut berdampak pada kerugian pihak lain.

Dalam hal ini perlu dipelajari bahwa antara Undang-Undang OJK dan UndangUndang Perbankan memiliki pengaturan mengenai ketentuan pidana dan sanksi administratif yang dapat dijatuhkan kepada pelaku Kejahatan di Bidang Perbankan.

Berdasarkan latar belakang masalah di atas, maka penulis melakukan penelitian yang dituangkan dalam jurnal berjudul "ANALISA PENJATUHAN SANKSI ADMINISTRASI

$\begin{array}{lcr}\text { DAN SANKSI } & \text { PIDANA } & \text { DALAM } \\ \text { PENANGANAN } & \text { TINDAK } & \text { PIDANA } \\ \text { PERBANKAN } & \text { DITINJAU } & \text { DARI } \\ \text { UNDANG-UNDANG NOMOR } & \text { TAHUN } \\ \text { 2011 TENTANG } & \text { OTORITAS } & \text { JASA } \\ \text { KEUANGAN DAN } & \text { UNDANG-UNDANG } \\ \text { NOMOR 7 TAHUN } & \text { 1992 } & \text { TENTANG } \\ \text { PERBANKAN } & & \text { BESERTA } \\ \text { PERUBAHANNYA". } & \end{array}$

\section{Rumusan Masalah}

Sehubungan dengan latar belakang masalah di atas, untuk membatasi ruang lingkup pembahasan materi dalam tesis ini maka identifikasi masalah yang akan penulis kemukakan adalah sebagai berikut:

1. Bagaimana penjatuhan sanksi administrasi dan sanksi pidana kepada Lembaga Jasa Keuangan di Sektor Perbankan yang 
melakukan pelanggaran sebagaimana diatur dalam Undang-Undang Nomor 21 Tahun 2011 tentang Otoritas Jasa Keuangan dan Undang-Undang Nomor 7 Tahun 1992 tentang Perbankan?

2. Bagaimana korelasi penerapan sanksi administratif dan penerapan ketentuan pidana dalam perkara tindak pidana perbankan dan pelanggaran di bidang perbankan?

3. Bagaimana perbandingan ketentuan pidana dan sanksi administratif di bidang perbankan di dalam Undang-Undang Nomor 21 Tahun 2011 tentang Otoritas Jasa Keuangan dan Undang-Undang Nomor 7 Tahun 1992 tentang Perbankan?

\section{Tujuan Penelitian}

Berdasarkan rumusan masalah di atas, maka tujuan utama dari penelitian ini adalah menilai penjatuhan sanksi pidana dan sanksi administratif kepada Lembaga Jasa Keuangan di bidang Perbankan. Selain itu juga melihat bagaimana korelasi penerapan sanksi administratif dan penerapan sanksi pidana dalam perkara pidana di bidang perbankan dan pelanggaran di bidang perbankan. Selanjutnya penelitian ini juga akan meneliti secara praktis perbandingan ketentuan pidana dan sanksi administratif antara Undang-Undang Nomor 21 Tahun 2011 tentang Otoritas Jasa Keuangan dan Undang-Undang Nomor 7 Tahun 1992 tentang Perbankan.

Oleh karena itu, dalam penelitian ini terdapat dua bagian daripada tujuan penulisan, antara lain:

1. Tujuan Umum

Untuk memahami bagaimana Undang Nomor 21 Tahun 2011 tentang Otoritas Jasa Keuangan dan Undang-Undang Nomor 7 Tahun 1992 tentang Perbankan mengatur mengenai ketentuan pidana dan sanksi administratif terhadap tindak pidana di bidang perbankan dan pelanggaran di bidang perbankan.

2. Tujuan Khusus

a. Menganalisis penjatuhan sanksi administratif dan sanksi pidana bagi tindak pidana dan pelanggaran di bidang perbankan. b. Menganalisis korelasi antar sanksi administratif dan sanksi pidana dalam perkara tindak pidana perbankan dan pelanggaran di bidang perbankan.

c. Menganalisis perbandingan pengaturan mengenai sanksi pidana dan sanksi administratif di bidang perbankan antara Undang Nomor 21 Tahun 2011 tentang Otoritas Jasa Keuangan dan Undang-Undang Nomor 7 Tahun 1992 tentang Perbankan.

\section{TINJAUAN PUSTAKA}

Perkembangan teknologi dan pertumbuhan ekonomi merupakan perkembangan yang dinilai positif bagi kemajuan suatu negara. Akan tetapi dalam perkembangan teknologi dan pertumbuhan ekonomi tersebut selalu merekat pula adanya perkembangan dalam kejahatan, salah satunya munculnya kejahatan di bidang perekonomian (economic crimes). Kejahatan yang demikian tersebut dilakukan untuk mengejar keuntungan bisnis (business profit oriented).

Konsep kejahatan di bidang perekonomian pertama kali dikemukakan oleh Edwin H. Sutherland dengan istilah Kejahatan Kerah Putih (white collar crime). Yaitu kejahatan yang dilakukan oleh seseorang yang memiliki titel terhormat, status sosial tinggi, dan kejahatan tersebut dilakukan dalam rangka melaksanakan pekerjaannya. Perlu dipahami bahwa konsep Kejahatan Kerah Putih tidak hanya ditujukan kepada subjek hukum perorangan (naturlijkpersoon) tetapi juga pada badan hukum (rechtpersoon). Adapun agar suatu tindak pidana perbankan dapat dijatuhkan kepada badan hukum maka harus terpenuhinya dua persyaratan tambahan (selain unsur pidana yang dikenakan), yaitu dilakukan dalam rangka big business dan perbuatannya telah menyalahgunakan kepercayaan masyarakat (in violation of public trust).

Salah satu kejahatan di bidang perekonomian tersebut adalah kejahatan di bidang perbankan. Dimana lembaga jasa keuangan di bidang perbankan merupakan lembaga keuangan yang menerima kepercayaan masyarakat untuk menghimpun dana masyarakat. Lembaga Jasa Keuangan di 
bidang perbankan sendiri memiliki peran yang sangat penting dan strategis dalam menggerakkan perekonomian nasional. Akan tetapi dalam perkembangannya, tindak pidana di bidang perbankan tersebut terus tumbuh seiring dengan bertumbuhnya perekonomian dan perkembangan teknologi, tidak hanya menjadi korban ada juga dalam beberapa kasus dimana pelaku kejahatan di bidang perbankan adalah pejabat atau lembaga jasa keuangan di bidang perbankan itu sendiri (criminal banking).

Kondisi yang demikian membawa para pembentuk hukum dan undang-undang menyusun ketentuan peraturan perundangundangan dalam rangka menanggulangi kejahatan dan pelanggaran di bidang perbankan. Salah satunya melalui Ketentuan Pidana dan Sanksi Administratif yang diterapkan di dalam Undang-Undang Nomor 21 Tahun 2011 tentang Otoritas Jasa Keuangan dan Undang-Undang Nomor 7 Tahun 1992 tentang Perbankan.

\section{Kegunaan Penelitian}

Dalam penelitian ini diharapkan dapat memberikan beberapa kegunaan dari sudut pandang teoritis dan praktis, antara lain:

1. Kegunaan Teoritis

Hasil penelitian ini diharapkan dapat memberikan sumbangan pemikiran dan pengembangan ilmu hukum, khususnya dalam bidang hukum perbankan. Sehingga dapat menjadi bahan pembelajaran bagi mahasiswa, dapat pula menjadi bahan pengujian dan pengkajian bagi akademisi di lingkungan civitas academica, dan dapat juga dipergunakan sebagai wadah sosialisasi tindak pidana perbankan dan pelanggaran perbankan kepada masyarakat umum.

2. Kegunaan Praktis

Hasil penelitian ini diharapkan dapat memberikan manfaat kepada pejabatpejabat di lingkungan Otoritas Jasa Keuangan, lembaga jasa keuangan di bidang perbankan, lembaga jasa keuangan selain di bidang perbankan, konsultan hukum, dan para pengusaha dalam menerapkan prinsip-prinsip kepatuhan hukum perbankan.

Selain itu hasil penelitian ini juga dapat dijadikan sebagai pedoman praktis bagi Penyidik Kepolisian Republik Indonesia, Penyidik Kejaksaan Agung Republik Indonesia, dan Hakim-hakim pada Mahkamah Agung Republik Indonesia.

\section{METODE PENELITIAN}

Metode penelitian ini disusun berdasarkan metode penelitian dan penulisan hukum. Dalam penelitian ini, tipe penelitian yang digunakan adalah tipe penelitian yang bersifat yuridis-normatif (legal-research), Terkait bahan hukum, penulis menggunakan tiga jenis bahan hukum, antara lain adalah bahan hukum primer, bahan hukum sekunder, dan bahan hukum tersier. Penelitian ini juga didukung dengan hasil wawancara dengan narasumber dan informan.

Berdasarkan sifatnya, penelitian ini bersifat deskriptif, yang dimaksudkan untuk memberikan data yang seteliti mungkin tentang manusia, keadaan, atau gejala-gejala lainnya. Sedangkan berdasarkan bentuknya, penelitian ini berbentuk penelitian preskriptif, yaitu penelitian yang bertujuan untuk mendapatkan saran-saran mengenai apa yang harus dilakukan untuk mengatasi masalahmasalah tertentu.

Pada penelitian ini, teknik pengumpulan data yang digunakan adalah dengan menggunakan pendekatan kualitatif dengan melakukan studi kepustakaan serta jenis data yang akan digunakan adalah data sekunder yang berupa bahan hukum primer dan bahan hukum sekunder sebagai berikut:

a) Data sekunder, yakni data yang diperoleh dari penelitian kepustakaan dan dilaksanakan dengan menginventarisasi seluruh peraturan dan data yang memiliki keterkaitan dengan obyek penulisan penelitian ini.

b) Sumber bahan hukum primer diperoleh dari peraturan perundangundangan terkait salah satunya yakni Undang-Undang Nomor 21 Tahun 2011 tentang Otoritas Jasa Keuangan, Undang-Undang Nomor 7 Tahun 
1992 tentang Perbankan, UndangUndang Nomor 10 Tahun 1998 tentang Perubahan Atas UndangUndang Nomor 7 Tahun 1992 tentang Perbankan, dan Peraturan Pemerintah Pengganti Undang-Undang Republik Indonesia Nomor 1 Tahun 2017 tentang Akses Informasi Keuangan Untuk Kepentingan Perpajakan. Selain itu Penulis juga melakukan studi terhadap Putusan-Putusan Pengadilan, baik itu Pengadilan Negeri, Pengadilan Tinggi, Mahkamah Agung, termasuk juga Putusan Mahkamah Konstitusi. Salah satu putusan yang menjadi bahan penelitian penulis yakni Putusan Mahkamah Konstitusi Nomor 64/PUU-X/2012 dan Putusan Mahkamah Konstitusi Nomor 109/PUU-XII/2014.

c) Sumber bahan hukum sekunder diperoleh melalui studi pustaka terhadap berbagai karya ilmiah dan pendapat sarjana yang terdapat dalam buku-buku atau literatur terkait pembahasan dalam penelitian, artikelartikel baik dalam media cetak maupun yang diperoleh dengan cara pengaksesan internet.

\section{TINJAUAN TEORITIS}

Sebagaimana yang diuraikan sebelumnya, perkembangan teknologi dan ekonomi juga berjalan seiringan dengan perkembangan kejahatan, termasuk di dalamnya kejahatan Perbankan. Sebenarnya hingga saat ini, tidak ada kesepakatan mengenai definisi daripada Kejahatan Perbankan itu sendiri. Akan tetapi dalam hal ini, para ahli hukum berpendapat bahwa tindak pidana di bidang perbankan dibagi dalam dua kelompok tindak pidana, pembagian mana didasarkan atas perbedaan perlakuan peraturan terhadap perbuatan-perbuatan yang telah melanggar hukum yang sehubungan dengan kegiatan-kegiatan dalam menjalankan usaha perbankan atau atas tindakan-tindakan yang berkaitan dengan Perbankan yang merupakan pelanggaran atau kejahatan, namun bukan dilakukan dalam rangka menjalankan usaha perbankan.Dalam UU Perbankan sendiri, Negara membagi Kejahatan Perbankan menjadi 2 (dua) jenis, yaitu kejahatan dan pelanggaran. Hal tersebut sebagaimana yang diatur di dalam Pasal 51 UU Nomor 7 Tahun 1992 tentang Perbankan beserta perubahanperubahannya ("UU Perbankan"), selengkapnya sebagai berikut:

"Pasal 51

(1) Tindak pidana sebagaimana dimaksud dalam Pasal 46, Pasal 47, Pasal 47A. Pasal 48 ayat (1). Pasal 49, Pasal 50, dan Pasal 50A adalah kejahatan.

(2) Tindak pidana sebagaimana dimaksud dalam Pasal 48 ayat (2) adalah pelanggaran."

Dari kutipan Pasal 51 di atas, maka dapat dilihat bahwa UU Perbankan membagi Kejahatan Perbankan dengan tindak pidana kejahatan yang diatur di dalam Pasal 46, Pasal 47, Pasal 47A. Pasal 48 ayat (1). Pasal 49, Pasal 50, dan Pasal 50A dan tindak pidana pelanggaran yang diatur di dalam Pasal 48 ayat (2).

Dalam hal ini untuk menanggulangi dan mencegah segala tindakan yang dapat berujung pada Kejahatan Perbankan serta mendorong adanya kepatuhan dalam menjalankan bisnis perbankan, Pemerintah sendiri menerapkan sanksi administratif dan sanksi pidana bagi pelaku Kejahatan Perbankan. Adapun penerapan sanksi administratif dan sanksi pidana tersebut diterapkan di dalam UU Perbankan. Bahwa sanksi administratif yang diatur di dalam UU Perbankan tersebut diatur sebagai berikut: "Pasal 52

(3) Dengan tidak mengurangi ketentuan pidana sebagaimana dimaksud dalam Pasal 47, Pasal 47A, Pasal 48, Pasal 49. dan Pasal 50A, Bank Indonesia dapat menetapkan sanksi administratif kepada bank yang tidak memenuhi kewajibannya sebagaimana ditentukan dalam Undang-undang ini, atau Pimpinan Bank Indonesia dapat mencabut izin usaha bank yang bersangkutan. 
(4) Sanksi administratif sebagaimana dimaksud dalam ayat (1), antara lain adalah:

a. denda uang;

b. teguran tertulis,

c. penurunan tingkat kesehatan bank;

d. larangan untuk turut serta dalam kegiatan kliring;

e. pembekuan kegiatan usaha tertentu, baik untuk kantor cabang tertentu maupun untuk bank secara keseluruhan;

f. pemberhentian pengurus bank dan selanjutnya menunjuk dan mengangkat pengganti sementara sampai Rapat Umum Pemegang Saham atau Rapat Anggota Koperasi mengangkat pengganti yang tetap dengan persetujuan Bank Indonesia.

g. pencantuman anggota pengurus, pegawai bank, pemegang saham dalam daftar orang tercela di bidang Perbankan.

(5) Pelaksanaan lebih lanjut mengenai sanksi administratif ditetapkan oleh Bank Indonesia

Pasal 53

Dengan tidak mengurangi ketentuan pidana sebagaimana dimaksud dalam Pasal 50, Bank Indonesia dapat menetapkan sanksi administratif kepada Pihak Terafiliasi yang tidak memenuhi kewajibannya sebagaimana ditentukan dalam Undang-undang ini atau menyampaikan pertimbangan kepada instansi yang berwenang untuk mencabut izin yang bersangkutan."

Bahwa dari kutipan diatas dapat dilihat bahwa sanksi administratif yang diterapkan terhadap Kejahatan Perbankan adalah sanksi yang dapat diberikan terhadap Bank atau Pihak Terafiliasi atas seluruh pelanggaran yang terjadi terhadap ketentuan UU Perbankan tanpa mengurangi keberlakuan dari sanksi pidana di dalam UU Perbankan itu sendiri. Sehingga sanksi administratif di dalam UU Perbankan dapat diberikan terlepas terpenuhinya ketentuan pidana atau tidak, selama terjadi pelanggaran atau ketidakpatuhan terhadap ketentuan di UU Perbankan, maka terhadap Bank maupun Pihak Terafiliasi dapat diberikan sanksi administratif.

Selain itu sanksi administratif juga dapat diberikan terhadap Bank atau Pihak Terafiliasi yang terbukti memenuhi ketentuan pidana yang diatur di dalam UU Perbankan. Sehingga dikenakannya sanksi pidana terhadap Bank atau Pihak Terafiliasi tidak serta-merta menghapus sanksi administratif, akan tetapi adanya tindak pidana perbankan justru memperkuat alasan diberikannya sanksi administratif.

Selanjutnya mengenai sanksi pidana yang diatur di dalam UU Perbankan, ketentuan pidana di dalam UU Perbankan diuraikan di dalam Pasal 46 hingga Pasal 50A dari UU Perbankan. Lebih lanjut Penulis mengutip selengkapnya sebagai berikut:

"Pasal 46

(1) Barang siapa menghimpun dana dari masyarakat dalam bentuk simpanan tanpa izin usaha dari Pimpinan Bank Indonesia sebagaimana dimaksud dalam Pasal 16, diancam dengan pidana penjara sekurang-kurangnya 5 (lima) tahun dan paling lama 15 (lima belas tahun serta denda sekurangkurangnya Rp10.000.000.000,00 (sepuluh miliar rupiah) dan paling banyak Rp200.000.000.000,00 (dua ratus miliar rupiah).

(2) Dalam hal kegiatan sebagaimana dimaksud dalam ayat (1) dilakukan oleh badan hukum yang berbentuk perseroan terbatas, perserikatan, yayasan atau koperasi, maka penuntutan terhadap badan-badan dimaksud dilakukan baik terhadap mereka yang memberi perintah melakukan perbuatan itu atau yang bertindak sebagai pimpinan dalam perbuatan itu atau terhadap keduaduanya.

Pasal 47

(1) Barang siapa tanpa membawa perintah tertulis atau izin dari Pimpinan Bank Indonesia sebagaimana dimaksud dalam Pasal 
41, Pasal 41A, dan Pasal 42, dengan sengaja memaksa bank atau Pihak Terafiliasi untuk memberikan keterangan sebagaimana dimaksud dalam Pasal 40, diancam dengan pidana penjara sekurang-kurangnya 2 (dua) tahun dan paling lama 4 (empat) tahun serta denda sekurang-kurangnya Rp10.000.000.000,00 (sepuluh miliar rupiah) dan paling banyak Rp200.000.000.000,00 (dua ratus miliar rupiah)

(2) Anggota Dewan Komisaris, Direksi, pegawai bank atau Pihak Terafiliasi lainnya yang dengan sengaja memberikan keterangan yang wajib dirahasiakan menurut Pasal 40, diancam dengan pidana penjara sekurang-kurangnya 2 (dua) tahun dan paling lama 4 (empat) tahun serta denda sekurang kurangnya Rp4.000.000.000,00 (empat miliar rupiah) dan paling banyak Rp8.000.000.000,00 (delapan miliar rupiah)

Pasal 48

(1) Anggota Dewan Komisaris, Direksi, atau pegawai bank yang dengan sengaja tidak memberikan keterangan yang wajib dipenuhi sebagaimana dimaksud dalam Pasal 30 ayat (1) dan ayat (2) dan Pasal 34 ayat (1) dan ayat (2), diancam dengan pidana penjara sekurang-kurangnya 2 (dua) tahun dan paling lama 10 (sepuluh) tahun serta denda sekurang-kurangnya Rp5.000.000.000,00 (lima miliar rupiah) dan paling banyak Rp100.000.000.000,00 (seratus miliar rupiah).

(2) Anggota Dewan Komisaris, Direksi, atau pegawai bank yang lalai memberikan keterangan yang wajib dipenuhi sebagaimana dimaksud dalam Pasal 30 ayat (1) dan ayat (2) dan Pasal 34 ayat (1) dan ayat (2), diancam dengan pidana kurungan sekurang-kurangnya 1 (satu) tahun dan paling lama 2 (dua) tahun dan atau denda sekurang-kurangnya
Rp1.000.000.000,00 (satu miliar rupiah) dan paling banyak Rp2.000.000.000,00 (dua miliar rupiah).

Pasal 49

(1) Anggota Dewan Komisaris, Direksi, atau pegawai bank yang dengan sengaja:

a. membuat atau menyebabkan adanya pencatatan palsu dalam pembukuan atau dalam laporan, maupun dalam dokumen atau laporan kegiatan usaha, laporan transaksi atau rekening suatu bank;

b. menghilangkan atau tidak memasukkan atau menyebabkan tidak dilakukannya pencatatan dalam pembukuan atau dalam laporan, maupun dalam dokumen atau laporan kegiatan usaha, laporan transaksi atau rekening suatu bank;

c. mengubah, mengaburkan, menyembunyikan, menghapus, atau menghilangkan adanya suatu pencatatan dalam pembukuan atau dalam laporan, maupun dalam dokumen atau laporan kegiatan usaha, laporan transaksi atau rekening suatu bank, atau dengan sengaja mengubah, mengaburkan, menghilangkan, menyembunyikan atau merusak catatan pembukuan tersebut, diancam dengan pidana penjara sekurang-kurangnya 5 (lima) tahun dan paling lama 15 (lima belas) tahun serta denda sekurang-kurangnya

Rp10.000.000.000,00 sepuluh miliar rupiah) dan paling banyak Rp200.000.000.000,00 (dua ratus miliar rupiah)

(2) Anggota Dewan Komisaris, Direksi atau pegawai bank yang dengan sengaja:

a. meminta atau menerima, mengizinkan atau menyetujui untuk menerima suatu imbalan, komisi, uang tambahan, pelayanan, uang 
atau barang berharga, untuk keuntungan pribadinya atau untuk keuntungan keluarannya, dalam rangka mendapatkan atau berusaha mendapatkan bagi orang lain dalam memperoleh uang muka, bank garansi, atau fasilitas kredit dari bank, atau dalam rangka pembelian atau pendiskontoan oleh bank atas surat-surat wesel, surat promes, cek, dan kertas dagang atau bukti kewajiban lainnya, ataupun dalam rangka memberikan persetujuan bagi orang lain untuk melaksanakan penarikan dana yang melebihi Batas kreditnya pada bank

b. tidak melaksanakan langkahlangkah yang diperlukan untuk memastikan ketaatan bank terhadap ketentuan dalam Undang-undang ini dan ketentuan peraturan perundang-undangan lainnya yang berlaku bagi bank, diancam dengan pidana penjara sekurang-kurangnya 3 (tiga) tahun dan paling lama 8 (delapan) tahun serta denda sekurang-kurangnya Rp5.000.000.000,00 (lima miliar rupiah) dan paling banyak Rp100.000.000.000,00 (seratus miliar rupiah).

Pasal 50

Pihak Terafiliasi yang dengan sengaja tidak melaksanakan langkah-langkah yang diperlukan untuk memastikan ketaatan bank terhadap ketentuan dalam Undang-undang ini dan peraturan perundang-undangan lainnya yang berlaku bagi bank, diancam dengan pidana penjara sekurangkurangnya 3 (tiga) tahun dan paling lama 8 (delapan) tahun serta denda sekurang-kurangnya Rp5.000.000.000,00 (lima miliar rupiah) dan paling banyak Rp100.000.000.000,00 (seratus miliar rupiah)

Pasal 50A
Pemegang saham yang dengan sengaja menyuruh Dewan Komisaris, Direksi, atau pegawai bank untuk melakukan atau tidak melakukan tindakan yang mengakibatkan bank tidak melaksanakan langkah-langkah yang diperlukan untuk memastikan ketaatan bank terhadap ketentuan dalam Undang-undang ini dan ketentuan peraturan perundang-undangan lainnya yang berlaku bagi bank, diancam dengan pidana penjara sekurang-kurangnya 7 (tujuh) tahun dan paling lama 15 (lima belas) tahun serta denda sekurang-kurangnya Rp10.000.000.000,00 (sepuluh miliar rupiah) dan paling banyak Rp200.000.000.000,00 (dua ratus miliar rupiah)."

Dari kutipan ketentuan pidana di dalam UU Perbankan di atas, dapat dilihat bahwa baik bagi Bank maupun Pihak Terafiliasi dapat dikenakan sanksi pidana apabila terbukti memenuhi ketentuan pidana kejahatan dan pelanggaran perbankan di atas. Selanjutnya apabila melihat ketentuan penerapan sanksi pidana dan sanksi administratif di dalam UU Perbankan tersebut, dapat dikatakan bahwa sanksi administratif dapat dipandang sebagai unsur pemberat pidana ataupun sebagai lembaga sanksi yang mengisi kekosongan ketentuan pidana pada ketidakpatuhan pasalpasal lain selain daripada yang ditentukan dalam ketentuan pidana.

Adapun selanjutnya perlu diperhatikan mengenai ketentuan sanksi pidana dan sanksi administratif di dalam Undang-Undang Nomor 21 Tahun 2011 tentang Otoritas Jasa Keuangan ("UU OJK"). Bahwa di dalam UU OJK sendiri tidak ada pengaturan spesifik mengenai sanksi administratif apa yang dapat diberikan terhadap pelanggar ketentuan UU OJK. Akan tetapi dalam hal ini perlu dipahami bahwa UU OJK selain merupakan ketentuan peraturan perundang-undangan yang mengatur mengenai lembaga jasa keuangan, tujuan utama dari UU OJK yang sebenarnya adalah untuk memuat ketentuan tentang organisasi dan tata kelola (governance) dari lembaga 
yang memiliki otoritas pengaturan dan pengawasan terhadap sektor jasa keuangan, yang mana dalam hal ini adalah OJK.

Bahwa dijelaskan di dalam Pasal 9 UU OJK, kewenangan pemberian sanksi administratif pada pihak-pihak yang melanggar ketentuan peraturan perundangundangan di sektor jasa keuangan ada pada OJK. Termasuk juga dalam hal ini pelanggaran ketentuan pada UU Perbankan, sanksi administratif yang diatur di dalam Pasal 52 dan 53 UU Perbankan, pengenaannya dijatuhkan oleh OJK.

Lebih lanjut di dalam UU OJK diatur mengenai ketentuan pidana atas pelanggaran UU OJK, selengkapnya dengan kutipan sebagai berikut:

"Pasal 52

(1) Setiap orang perseorangan yang melanggar ketentuan Pasal 33 ayat (1), ayat (2), dan/atau ayat (3), dipidana dengan pidana penjara paling lama 6 (enam) tahun dan pidana denda paling banyak Rp15.000.000.000,00 (lima belas miliar rupiah).

(2) Apabila pelanggaran terhadap ketentuan Pasal 33 ayat (2) dan/atau ayat (3) dilakukan oleh korporasi, dipidana dengan pidana denda paling banyak Rp45.000.000.000,00 (empat puluh lima miliar rupiah) dan/atau sebesar jumlah kerugian yang ditimbulkan akibat pelanggaran tersebut.

Pasal 53

(1) Setiap Orang yang dengan sengaja mengabaikan, tidak memenuhi, atau menghambat pelaksanaan kewenangan OJK sebagaimana dimaksud dalam Pasal 9 huruf c, huruf $d$, huruf e, huruf $f$, huruf g, dan/atau Pasal 30 ayat (1) huruf a, dipidana dengan pidana penjara paling singkat 2 (dua) tahun dan pidana denda paling sedikit Rp5.000.000.000,00 (lima miliar rupiah) atau pidana penjara paling lama 6 (enam) tahun dan pidana denda paling banyak Rp15.000.000.000,00 (lima belas miliar rupiah).
(2) Apabila pelanggaran sebagaimana dimaksud pada ayat (1) dilakukan oleh korporasi, dipidana dengan pidana denda paling sedikit Rp15.000.000.000,00 (lima belas miliar rupiah) atau paling banyak Rp45.000.000.000,00 (empat puluh lima miliar rupiah).

Pasal 54

(1) Setiap Orang yang dengan sengaja mengabaikan dan/atau tidak melaksanakan perintah tertulis sebagaimana dimaksud dalam Pasal 9 hurufd atau tugas untuk menggunakan pengelola statuter sebagaimana dimaksud dalam Pasal 9 huruf $f$, dipidana dengan pidana penjara paling singkat 2 (dua) tahun dan pidana denda paling sedikit Rp5.000.000.000,00 (lima miliar rupiah) atau pidana penjara paling lama 6 (enam) tahun dan pidana denda paling banyak Rp15.000.000.000,00 (lima belas miliar rupiah).

(2) Apabila pelanggaran sebagaimana dimaksud pada ayat (1) dilakukan oleh korporasi, korporasi dipidana dengan pidana denda paling sedikit Rp15.000.000.000,00 (lima belas miliar rupiah) atau paling banyak Rp45.000.000.000,00 (empat puluh lima miliar rupiah)."

Bahwa di dalam ketentuan pidana di dalam UU OJK, membahas mengenai pelanggaran atas pasal-pasal 9, 30 ayat (1), 33 dari UU OJK. Oleh karena itu dalam hal ini Penulis juga mengutip pasal-pasal tersebut sebagai berikut: "Pasal 9

Untuk melaksanakan tugas pengawasan sebagaimana dimaksud dalam Pasal 6, OJK mempunyai wewenang:

a. menetapkan kebijakan operasional pengawasan terhadap kegiatan jasa keuangan;

b. mengawasi pelaksanaan tugas pengawasan yang dilaksanakan oleh Kepala Eksekutif;

c. melakukan pengawasan, pemeriksaan, 
perlindungan Konsumen, dan tindakan lain terhadap Lembaga Jasa Keuangan, pelaku, dan/atau penunjang kegiatan jasa keuangan sebagaimana dimaksud dalam peraturan perundang-undangan di sektor jasa keuangan;

d. memberikan perintah tertulis kepada Lembaga Jasa Keuangan dan/atau pihak tertentu;

e. melakukan penunjukan pengelola statuter;

f. menetapkan penggunaan pengelola statuter;

g. menetapkan sanksi administratif terhadap pihak yang melakukan pelanggaran terhadap peraturan perundangundangan di sektor jasa keuangan; dan ...

Pasal 30

(1) Untuk perlindungan Konsumen dan masyarakat, OJK berwenang melakukan pembelaan hukum, yang meliputi:

a. memerintahkan atau melakukan tindakan tertentu kepada Lembaga Jasa Keuangan untuk menyelesaikan pengaduan Konsumen yang dirugikan Lembaga Jasa Keuangan dimaksud;

b. mengajukan gugatan:

1. untuk memperoleh kembali harta kekayaan milik pihak yang dirugikan dari pihak yang menyebabkan kerugian, baik yang berada di bawah penguasaan pihak yang menyebabkan kerugian dimaksud maupun di bawah penguasaan pihak lain dengan itikad tidak baik; dan/atau

2. untuk memperoleh ganti kerugian dari pihak yang menyebabkan kerugian pada Konsumen dan/atau Lembaga Jasa Keuangan sebagai akibat dari pelanggaran atas peraturan perundang-undangan di sektor jasa keuangan ...

Pasal 33
(1) Setiap orang perseorangan yang menjabat atau pernah menjabat sebagai anggota Dewan Komisioner, pejabat atau pegawai OJK dilarang menggunakan atau mengungkapkan informasi apa pun yang bersifat rahasia kepada pihak lain, kecuali dalam rangka pelaksanaan fungsi, tugas, dan wewenangnya berdasarkan keputusan OJK atau diwajibkan oleh Undang-Undang

(2) Setiap Orang yang bertindak untuk dan atas nama OJK, yang dipekerjakan di OJK, atau sebagai staf ahli di OJK, dilarang menggunakan atau mengungkapkan informasi apa pun yang bersifat rahasia kepada pihak lain, kecuali dalam rangka pelaksanaan fungsi, tugas, dan wewenangnya berdasarkan keputusan OJK atau diwajibkan oleh UndangUndang

(3) Setiap Orang yang mengetahui informasi yang bersifat rahasia, baik karena kedudukannya, profesinya, sebagai pihak yang diawasi, maupun hubungan apa pun dengan OJK, dilarang menggunakan atau mengungkapkan informasi tersebut kepada pihak lain, kecuali dalam rangka pelaksanaan fungsi, tugas, dan wewenangnya berdasarkan keputusan OJK atau diwajibkan oleh UndangUndang “

Dari kutipan mengenai ketentuan pidana dari UU OJK diatas, maka dapat dipelajari bahwa secara garis besar ketentuan pidana yang dibahas di dalam UU OJK merupakan ketentuan pidana yang membahas mengenai tindakan-tindakan daripada orangorang atau pihak-pihak yang dapat mengakibatkan terhalangnya pelaksanaan kewajiban dan kewenangan OJK. Selain itu ketentuan pidana di atas juga mengatur mengenai kewajiban dalam menjaga informasi rahasia yang mana hal tersebut tidak diatur di dalam UU Perbankan. Bahwa dikarenakan lebih luasnya subjek dan lingkup yang diatur di dalam Ketentuan Pidana UU OJK, maka dapat diketahui bahwa dalam menunjuk subjek 
hukum yang dapat dimintakan pertanggungjawaban pidana, UU OJK tidak hanya merujuk pada Bank dan Pihak Terafiliasi, tetapi juga pada pihak-pihak lain daripada itu selama dapat dibuktikan bahwa pihak tersebut memenuhi ketentuan pidana di dalam UU OJK.

\section{HASIL PENELITIAN DAN PEMBAHASAN}

Bahwa setelah melakukan penelitian atas UU OJK dan UU Perbankan, dapat dilihat bahwa terdapat perbandingan yang jelas antara ketentuan pidana yang berada di dalam UU OJK dan UU Perbankan. Bahwa di dalam UU OJK, ketentuan pidana yang diatur adalah Kejahatan Perbankan yang dilakukan di luar konteks menjalankan usaha jasa perbankan. Sementara itu, ketentuan pidana yang diatur di dalam UU Perbankan adalah Kejahatan Perbankan yang dilakukan dalam konteks menjalankan usaha perbankan itu sendiri. Sehingga apabila mengambil definisi Kejahatan Perbankan oleh Mardjono Reksodiputro, maka ketentuan pidana yang diatur di dalam UU Perbankan lebih cocok untuk dikatakan sebagai Kejahatan Perbankan, dimana Kejahatan Perbankan adalah kejahatan yang dilakukan dalam rangka menjalankan usaha perbankan.

Selain itu berdasarkan penelitian yang dilakukan, ditemukan pula perbedaan mendasar mengenai subjek hukum dari ketentuan pidana yang diatur. Bahwa di dalam ketentuan pidana UU Perbankan, subjek hukum yang ditunjuk secara garis besar merupakan lembaga jasa keuangan di bidang perbankan dan Pihak Terafiliasi. Sementara itu di dalam UU OJK, subjek hukum yang ditunjuk di dalam ketentuan pidananya adalah setiap orang yang terbukti melakukan tindak pidana yang diatur, terlepas apakah itu lembaga jasa keuangan perbankan, Pihak Terafiliasi, ataupun pihak-pihak di luar itu.

Selain itu dari penelitian di atas juga diketahui bahwa sanksi administratif dapat dijatuhkan baik itu ada pelanggaran pidana atau tidak. Penjatuhan sanksi administratif dapat dibarengi dengan penjatuhan sanksi pidana ataupun tanpa adanya penjatuhan sanksi pidana, selama ketentuan UU Perbankan dan peraturan perundang-undangan lainnya dilanggar oleh siapa saja dalam hal menjalankan kegiatan usaha perbankan atau dalam hal lain diluar menjalankan kegiatan usaha perbankan, sanksi administratif dapat dijatuhkan oleh OJK.

\section{SIMPULAN}

Bahwa dari penelitian di atas, didapatkan kesimpulan-kesimpulan mengenai sanksi pidana dan sanksi administratif serta korelasinya di dalam UU Perbankan dan UU OJK serta sebagai berikut:

1. Berdasarkan UU OJK, OJK merupakan pihak yang berwenang untuk menjalankan penjatuhan sanksi administratif terhadap siapapun yang melanggar ketentuan peraturan perundang-undangan tentang perbankan.

2. Sanksi administratif dapat dijatuhkan kepada siapapun yang melanggar ketentuan peraturan perundang-undangan di bidang perbankan, tanpa melihat ada atau tidak terpenuhinya ketentuan pidana,

3. Ketentuan Pidana di UU OJK menitikberatkan pada Kejahatan Perbankan di luar konteks menjalankan usaha perbankan. Sementara Ketentuan Pidana di UU Perbankan merupakan Kejahatan Perbankan yang dilakukan dalam rangka menjalankan usaha perbankan.

\section{SARAN}

Bahwa dikarenakan terdapat tumpang tindih pengaturan sanksi administratif dan kewenangan penjatuhan sanksi administratif dalam hal adanya Kejahatan atau Pelanggaran di bidang perbankan. Penulis memberikan saran kepada pembentuk peraturan perundangundangan untuk menyelaraskan ketentuan mengenai sanksi administratif di dalam satu undang-undang.

Bahwa dikarenakan adanya kesimpangsiuran mengenai definisi Kejahatan Perbankan. Penulis memberikan saran kepada pembentuk peraturan perundang-undangan untuk memberikan definisi yang jelas mengenai Kejahatan Perbankan. Penulis menilai bahwa diperlukan adanya penegasan 
definisi dari Kejahatan Perbankan agar tidak terdapat penafsiran yang keliru dalam memahami Kejahatan Perbankan.

Bahwa dikarenakan adanya keterkaitan antara ketentuan-ketentuan di dalam UU OJK dan UU Perbankan, Penulis memberikan saran kepada akademisi untuk membuat konsolidasi peraturan yang berkaitan dengan kegiatan perbankan dan kejahatan perbankan, termasuk juga konsolidasi dari peraturan perundangundangan lainnya yang berkaitan dengan perbankan dan Kejahatan Perbankan.

\section{DAFTAR PUSTAKA}

Anwar, H.A.K. Moch. Hukum Pidana di Bidang Ekonomi. Cet. ke-5. Bandung: PT Citra Aditya Bakti. 1990.

Arief, Barda Nawawi. Batas-batas Kemampuan Hukum Pidana Dalam Penanggulangan Kejahatan. Makalah disampaikan pada Seminar Nasional Pendekatan Non-penal Dalam Penanggulangan Kejahatan yang diselenggarakan oleh Fakultas Hukum UNDIP Semarang. 2 September 1996.

Ibrahim, Johannes dan Hassanain Haykal. "Pertanggungjawaban Pidana Bank Dalam Pelanggaran Kegiatan Operasional Didasarkan Pada Undang-Undang Nomor 10 Tahun 1998". Jurnal Hukum Bisnis dan Investasi. Vol. 7. No. 2. April 2016. Hlm. 42-53.

Indonesia. Undang-undang tentang Otoritas Jasa Keuangan. UU Nomor 21 Tahun 2011. LN No. 11 Tahun 2011. TLN No. 5253.

Indonesia. Undang-Undang tentang Perbankan. UU Nomor 7 Tahun 1992. LN No. 32 Tahun 1992. TLN No. 3473.

Indonesia. Undang-Undang tentang Perubahan Atas Undang-Undang Nomor 7 Tahun 1992 tentang Perbankan. UU Nomor 10 Tahun 1998. LN No. 182 Tahun 1998. TLN No. 3790.
Jonker. Tanggung Jawab Yuridis Bankir Atas Kredit Macet Nasabah. Bandung: Alumni. 2009.

Marpaung, Leden. Kejahatan Terhadap Perbankan. Jakarta: Erlangga. 1993.

Otoritas Jasa Keuangan. Pahami \& Hindari: Buku Memahami dan Menghindari Tindak Pidana Perbankan. S.1. S.n. S.a.

Reksodiputro, Mardjono. Bunga Rampai Permasalahan dalam Sistem Peradilan Pidana. Jakarta: Pusat Pelayanan Keadilan dan Pengabdian Hukum. 2007.

Reksodiputro, Mardjono. Kemajuan Perkembangan Ekonomi dan Kejahatan, Kumpulan Karangan Buku Kesatu. Cet. ke-1. Jakarta: Pusat Pelayanan Keadilan dan Pengabdian Hukum Lembaga Kriminologi Universitas Indonesia. 1994.

Soekanto, Soerjono. Pengantar Penelitian Hukum. Jakarta: Universitas Indonesia (UI-Press). 2012.

Sutherland, Edwin H. White Collar Crime. New York: The Dryden Pers. 1942.

Utrecht, E. Pengantar Dalam Hukum Indonesia. Jakarta: PT Ichtiar Baru. 1989. 